Agro-Science Journal of Tropical Agriculture, Food, Environment and Extension Volume 12 Number 3 September 2013 pp. $1-8$

ISSN 1119-7455

\title{
EFFECTS OF RUMEN DIGESTA ON THE PHYSICO-CHEMICAL PROPERTIES OF SOIL IN NSUKKA, SOUTHEASTERN NIGERIA
}

\author{
Edeh, I.G., Igwe, C.A. and Ezeaku P.I. \\ Department of Soil Science and Land Resources Management, Faculty of Agriculture, University of \\ Nigeria, Nsukka. 410001. Nigeria. \\ *Corresponding author: ifeoma.edeh@unn.edu.ng \\ Other authors email: charigwe1@ @otmail.com, peter.ezeaku@unn.edu.ng
}

\begin{abstract}
In tropical and subtropical areas, the importance of organic manure in improving soil physico-chemical properties and crop production for food security cannot be overemphasized. A study was conducted during 2012/2013 crop years, to investigate the effects of rumen digesta on the physical and chemical properties of soil in Nsukka, Enugu State, Nigeria. Soil samples were collected from Opi, Nsukka and treated to four rates of rumen digesta (viz. 0, 50, 100, and $150 \mathrm{gkg}^{-1}$ soils). Physical and chemical properties of the soil were determined pre and post-experiment. The results obtained revealed that rumen digesta significantly $(p=0.05)$ increased the mean weight diameter (0.49 to $1.75 \mathrm{~mm})$, aggregate stability (54.7\% to $75.3 \%)$, soil $\mathrm{pH}(3.8$ to 7.8$)$, total nitrogen $(0.01 \%$ to $0.02 \%)$, exchangeable sodium and potassium $\left(0.22\right.$ to $4.39 \mathrm{cmolkg}^{-1}$ for $\mathrm{Na}^{+}$and 0.30 to $4.31 \mathrm{cmolkg}^{-}$ for $\left.\mathrm{K}^{+}\right), \mathrm{CEC}\left(7.2\right.$ to $\left.14.9 \mathrm{cmolkg}^{-1}\right)$ and organic matter content $(0.97 \%$ to $4.29 \%)$. It had no significant effect on the texture, micro-aggregate (measured as dispersion ratio), exchangeable calcium and magnesium content of the soils. The study found significant reduction in the exchangeable aluminum (1.5 to $\left.0.0 \mathrm{cmolkg}^{-1}\right)$ and hydrogen (3.7 to $2.2 \mathrm{cmolkg}^{-1}$ ) contents of the soils. Farmers can therefore improve the physical and chemical properties of soils by using rumen digesta as an alternative liming material.
\end{abstract}

Keywords: Rumen digesta, soil properties, fertilizer use, Nsukka-Nigeria

\section{INTRODUCTION}

The use of organic manures (especially ruminant dung, poultry droppings, household refuse and effluents) for crop production is an agelong agricultural practice among the subsistence farming communities in West African subregion (Lombin et al., 1991). In many developing countries like Nigeria, the likelihood of obtaining enough synthetic fertilizers to meet the food crop requirement of the teeming farming population is remote. The ever-increasing demand for food has intensified the quest for more production per unit area and for an increase product of land under arable cultivation. Farmers in the tropics and the subtropics have been forced to eliminate fallow periods and rely on synthetic fertilizers. These practices (reduction in fallow periods and increased use of synthetic fertilizers) have lead to the increment in land degradation and decline of crop productivity. Odu and Mba (1991) stated that inorganic fertilize supply nutrients alone, while organic manures not only supply nutrient elements through microbial activities but also help in improving the soil physico-chemical properties.
The inventory of urban and industrial wastes in Nigeria, as compiled by Sridar (2006) showed that millions of tons of industrial, domestic and animal wastes so produced annually in the country are not effectively utilized whereas these wastes can be utilized effectively for agriculture. Evidences indicate that by judicious application of these wastes on agricultural field one could maintain a high level of soil fertility. Investigations on the possible use of organic wastes to improve the productivity of soils have been carried out (Agbim, 1981; Omaliko \& Agbim, 1983; Mbagwu 1985; Omaliko 1985).

The use of organic wastes as biofertilizers has necessitated many studies aimed at evaluating the fertilizing value of these organic waste products (poultry dropping, cow dung, and sewage sludge and swine wastes) to ascertain their potentials in improving soil fertility. However there is little information available about the effect of rumen digesta on the physical and chemical properties of soils in the study area. Rumen digesta are water and the associated 
water from an abattoir emanating from the paunch content (rumen) of ruminant animals, they are part of organic wastes or manures. A total of $194 \mathrm{~kg}$ of solid (rumen/stomach) waste is generated daily in Nsukka abattoir (Nwanta et al., 2010), therefore it will be beneficial to study its effect on the physical and chemical properties of soils. The objective of the study therefore, was to determine the effects of rumen digesta on the physico-chemical properties of soils from Opi in Nsukka Local Government Area (L.G.A) of Enugu State, Nigeria.

\section{MATERIALS AND METHOD \\ Study Area}

The experiment was carried out at the greenhouse of the Faculty of Agriculture, University of Nigeria, Nsukka. The soil sample was collected from a farmer's field at Opi while the rumen digesta was collected from Ikpa abattoir in Nsukka, Enugu State. Nsukka is located at latitude $06^{0} 52 \mathrm{~N}$ and longitude $07^{0} 24 \mathrm{E}$ on an altitude of approximately $400 \mathrm{~m}$ above sea level. Generally the climate of Nsukka is characterized by mean annual rainfall of about $1600 \mathrm{~mm}$ and mean annual evapotranspiration (ET) of about $1560 \mathrm{~mm}$. The ET however exceeds total rainfall in most months of the year (Igwe, 2004).. Temperature is uniformly high throughout the year, with mean minimum and maximum annual values of $21^{\circ} \mathrm{C}$ and $31^{\circ} \mathrm{C}$ respectively. Rarely does temperature exceed $35^{\circ} \mathrm{c}$ during the hottest months (Asadu, 1990; Obi and Salako, 1995).

Grassland vegetation is predominant in the study location which according to Mbagwu (1991) is within the forest-savanna transition vegetation zone. The area has an ustic soil moisture regime and the soil around are characterized as being well drained with very low total exchangeable base, cation exchange capacity(CEC) and base saturation (Asadu, 1990). The soil is deep, coarse textured and low in organic matter with perennial leaching problem (Igwe 2004). The soils mostly belong to the order of Ultisol and Vertisol.

\section{Sample Collection}

From a farmers' farm field $\left(0.05 \mathrm{~km}^{2}\right)$ at Opi in Nsukka LGA of Enugu State, auger samples were collected at a depth of $0-30 \mathrm{~cm}$ from randomly selected positions. The samples were bulked to get composite samples and transported to the greenhouse. The soil samples were air dried and sieved through a
$2 \mathrm{~mm}$ mes and stored in 12 plastic containers (1564 $\mathrm{cm}^{3}$ ) before amendments were applied. The rumen digesta was collected from the paunch content of cattles, from Ikpa-Nsukka abattoir, Enugu State and air dried.

\section{Experimental Design}

One $\mathrm{kg}$ of soil was measured into plastic containers and treated with the waste at the rates of $0,50,100$, and 150 g. Experimental design was completely randomized design (CRD) and treatments were replicated 3 times resulting to a total of 12 potted soils The treated soil samples were kept moist with distilled water (200 $\mathrm{ml}$ daily) during the 5 weeks duration of the experiment. The soil samples were analyzed for physical and chemical properties before and after amendment, while the rumen digesta was analyzed for its chemical properties before application.

\section{Laboratory Studies}

The laboratory analysis was conducted at the Soil Science laboratory, Faculty of Agriculture, University of Nigeria, Nsukka. The physical properties analysed were as follows: particle size distribution was determined using the hydrometer method (Bouyoucos 1962), Dispersion ratio, and the water stable aggregate of the soils which were determined by wet - sieving method of Kemper and Rosenau (1986). Aggregate stability was calculated as thus;

$\frac{\text { weight of stable aggregate-weight of sand }}{\text { weight of sample-weight of sand }} \times 100$ -eq (1)

Chemical properties analysed were: soil $\mathrm{pH}$ determined using glass electrode $\mathrm{pH}$ meter in water in the ratio of 1:2.5 (Maclean, 1982), organic carbon content determined by wet dichromate acid oxidation method (Nelson and Sommers 1982); and organic matter by multiplying organic carbon by a factor of 1.724. Total nitrogen was determined by using kjeldahl apparatus (Bremner and Mulvaney 1982), Exchangeable base by ammonium acetate leaching and exchangeable acidity by titration (MaClean, 1982). The effective cation exchangeable capacity (ECEC) was determined by summation of exchangeable bases and exchangeable acidity.

\section{Statistical analysis}

All data collected were statistically analyzed using Genstat 9.2 edition 


\section{RESULTS AND DISCUSSION}

The chemical properties of the rumen digesta are shown in Table 1. The $\mathrm{pH}$ is 8.0 (alkaline in character).

The physical and chemical properties of the soil before application of rumen digesta are shown in Table 2. The soil has sandy clay loam texture. The percentage water dispersible (WD) clay and silt is $10 \%$. Chemically, the soil is highly acidic ( $\mathrm{pH} 3.1)$ with low percentage organic carbon $(0.54 \%)$ and total nitrogen contents $(0.11 \%)$. Generally the values of exchangeable cations $\left(\mathrm{Ca}^{2+}, \mathrm{Mg}^{2+}, \mathrm{K}^{+}\right.$and $\left.\mathrm{Na}^{+}\right)$are low according to Mbagwu (1992).

\section{Physical Properties}

The results of the soil particle size distribution (PSD) at different rates of rumen digesta application are presented in Table 3. There were no significant differences $(\mathrm{p}=0.05)$ between the \%clay, \%silt, and $\%$ total sand content and textural class of the treated soils and the untreated soils.
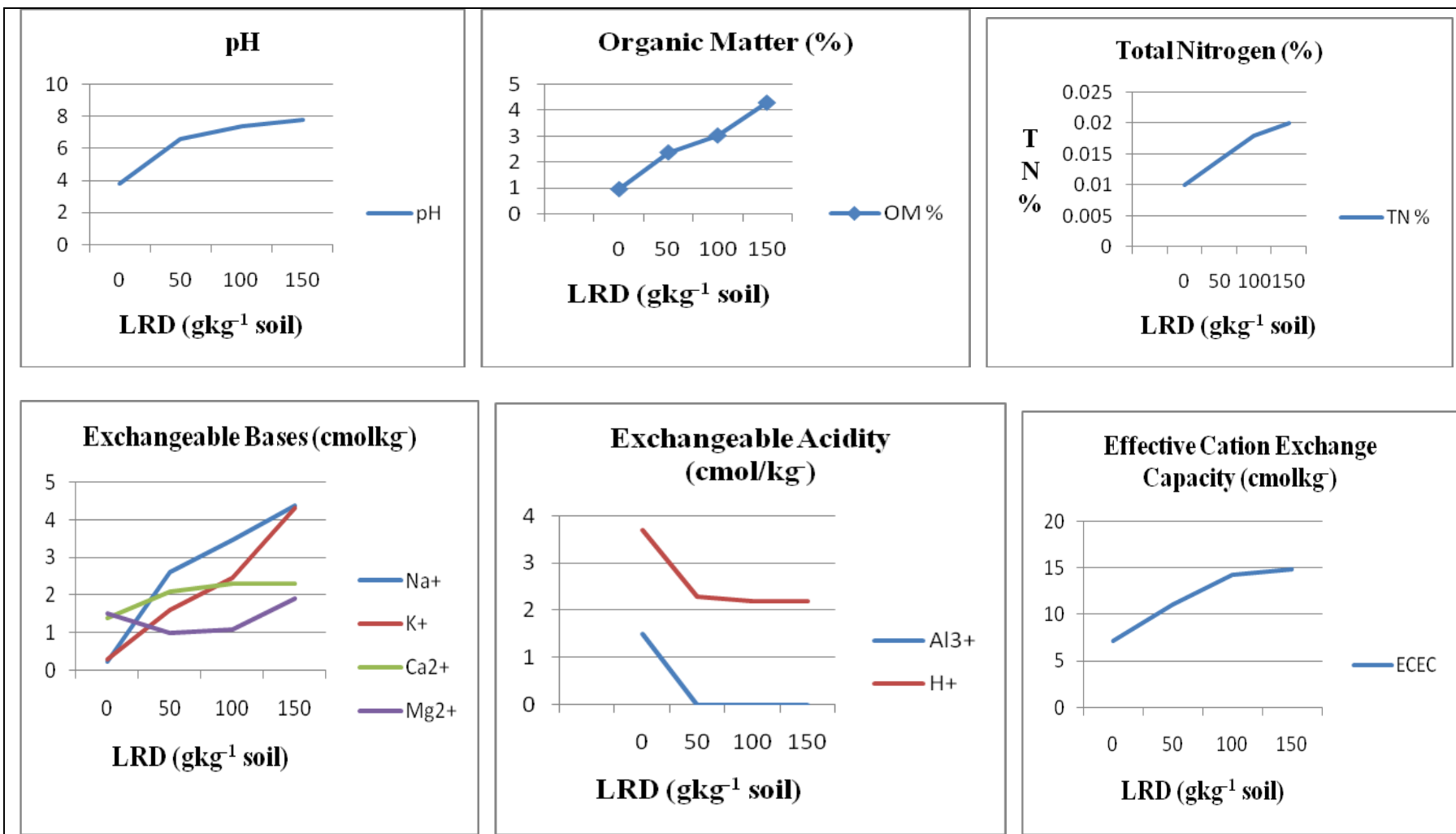

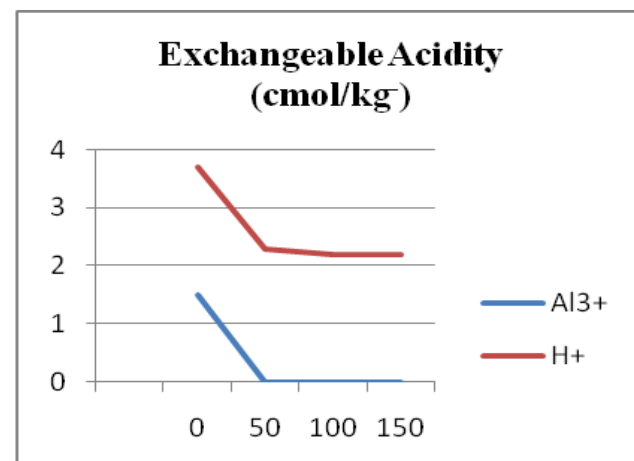

LRD ( gkg $^{-1}$ soil $)$

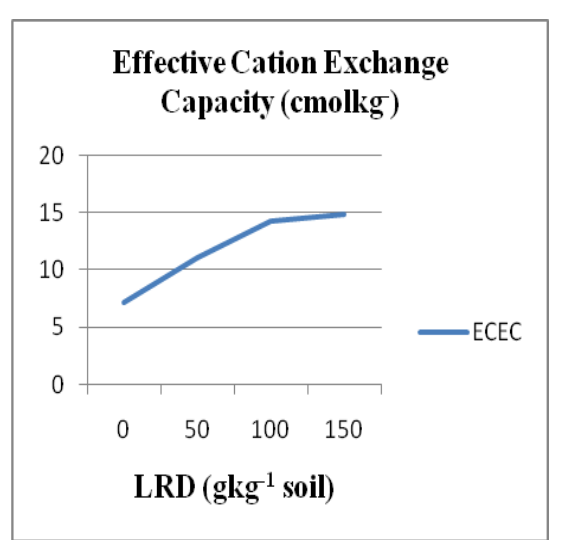

LRD $\left(\mathrm{gkg}^{-1}\right.$ soil $)$

Fig 1: Effect of rumen digesta on the organic matter content, total nitrogen, exchangeable bases, exchangeable acidity and cation exchange capacity. LRD = level of rumen digesta application

Table: 1 Chemical properties of rumen digesta (RD)

\begin{tabular}{ll}
\hline Parameter & Value \\
\hline $\mathrm{pH} \mathrm{H} \mathrm{H}_{2} \mathrm{O}$ & 8.0 \\
$\mathrm{OC} \%$ & 28.15 \\
$\mathrm{TN} \%$ & 0.023 \\
$\mathrm{Na}^{+} \mathrm{cmol} / \mathrm{kg}$ & 24.21 \\
$\mathrm{~K}^{+} \mathrm{cmol} / \mathrm{kg}$ & 28.68 \\
$\mathrm{Ca}^{2+} \mathrm{cmol} / \mathrm{kg}$ & 3.2 \\
$\mathrm{Mg}^{2+} \mathrm{cmol} / \mathrm{kg}$ & 4.6 \\
$\mathrm{Al}^{3+} \mathrm{cmol} / \mathrm{kg}$ & 0.00 \\
$\mathrm{H}^{+} \mathrm{cmol} / \mathrm{kg}$ & 33.46 \\
\hline
\end{tabular}

$\mathrm{OC}=$ organic carbon, $\mathrm{TN}=$ total nitrogen. 
Table 2: Initial soil analysis result

\begin{tabular}{|c|c|c|}
\hline Parameters & & Value \\
\hline \multirow{10}{*}{$\begin{array}{l}\text { Physical } \\
\text { properties }\end{array}$} & Clay (\%) & 20 \\
\hline & Silt (\%) & 4 \\
\hline & T. sand (\%) & 76 \\
\hline & Textural Class & Sandy Clay Loam \\
\hline & WD Clay (\%) & 10 \\
\hline & WD Silt (\%) & 10 \\
\hline & DR & 0.77 \\
\hline & CDR & 0.5 \\
\hline & MWD (mm) & 0.47 \\
\hline & $\operatorname{AS}(\%)$ & 53 \\
\hline \multirow{11}{*}{$\begin{array}{l}\text { Chemical } \\
\text { properties }\end{array}$} & $\mathrm{pH}$ & 3.1 \\
\hline & $\mathrm{OC}(\%)$ & 0.54 \\
\hline & $\mathrm{OM}(\%)$ & 0.93 \\
\hline & $\mathrm{TN}(\%)$ & 0.011 \\
\hline & $\mathrm{Na}^{+}(\mathrm{cmol} / \mathrm{kg})$ & 0.22 \\
\hline & $\mathrm{K}^{+}(\mathrm{cmol} / \mathrm{kg})$ & 0.39 \\
\hline & $\mathrm{Ca}^{2+}(\mathrm{cmol} / \mathrm{kg})$ & 1.2 \\
\hline & $\mathrm{Mg}^{2+}(\mathrm{cmol} / \mathrm{kg})$ & 2.4 \\
\hline & $\mathrm{Al}^{3+}(\mathrm{cmol} / \mathrm{kg})$ & 0.8 \\
\hline & $\mathrm{H}^{+}(\mathrm{cmol} / \mathrm{kg})$ & 4.4 \\
\hline & $\mathrm{CEC}(\mathrm{cmol} / \mathrm{kg})$ & 6.4 \\
\hline
\end{tabular}

Table 3: Particle size distribution of the soils of Opi-Nsukka

\begin{tabular}{|c|c|c|c|c|}
\hline $\begin{array}{l}\text { Rumen digesta }\left(\mathrm{gkg}^{-1}\right. \\
\text { soil) }\end{array}$ & Clay & Silt & Total Sand & Textural Class \\
\hline 0 & 20 & 4 & 76 & Sandy clay loam \\
\hline 50 & 21 & 5 & 74 & Sandy clay loam \\
\hline 100 & 20 & 6 & 74 & Sandy clay loam \\
\hline 150 & 19 & 5 & 76 & Sandy clay loam \\
\hline $\mathrm{LSD}_{0.05}$ & n.s & n.s & n.s & \\
\hline
\end{tabular}

In Table 4, there was no significant difference between the DR of the treated soils and the untreated soils. The DR of the untreated soil was 0.76 while that of the treated soils range from 0.75 to 0.84 . This is similar to the result by Mbah and Onweramadu (2009) which showed that additions of soil organic amendments failed to significantly improve micro-aggregate stability (measured as dispersion ratio).

The soil weight at $>2 \mathrm{~mm}, 2-1 \mathrm{~mm}, 1-0.5 \mathrm{~mm}$, $0.5-0.25 \mathrm{~mm}$ and $<0.25 \mathrm{~mm}$, mean-weight diameter and aggregate stability at different rates of rumen digesta application are presented in Table 5. Positive significant differences $(p=0.05)$ in the weights of the soil, MWD and AS were recorded due to the application of rumen digesta. The variables increased as the rate of rumen digesta applied increased.

Table 5 shows the water-stable aggregate, mean-weight diameter and aggregate stability. There were significant differences $(\mathrm{p}=0.05)$ between the mean weight diameter (MWD) of the treated soils and the untreated soils. Rumen digesta significantly increased the mean weight diameter as the application rate increased. MWD value obtained at $150 \mathrm{gkg}^{-}$soil was significantly higher than the control by $27.4 \%$.

There was significant differences $(\mathrm{p}=0.05)$ between the aggregate stability (AS) of the treated soils and the untreated soils. Rumen digesta significantly increased the aggregate stability of the soils as the application rate increased. The AS of the untreated soil was 54\% while the the treated soils ranged from 69.3 to $75.3 \%$. This could be due to the binding power of organic matter on soil particles to form stable aggregates. This is in accordance with the research findings by Chaney and Swift (2006); El hadj et al. (2013); Nwite (2013); Mbah and Onweremadu (2009). 
Table 4: Water-dispersible particle size distribution of the soils of Opi-Nsukka

\begin{tabular}{lllll}
\hline Rumen digesta $\left(\mathrm{gkg}^{-1}\right.$ soil $)$ & WD Clay\% & WD Silt $\%$ & DR & CDR \\
\hline 0 & 9 & 12 & 0.76 & 0.45 \\
50 & 10 & 8 & 0.75 & 0.5 \\
100 & 13 & 8 & 0.84 & 0.93 \\
150 & 14 & 6 & 0.84 & 1.0 \\
L.S.D & n.s & n.s & n.s & n.s \\
\hline \multicolumn{2}{l}{ WD clay = water dispersible clay, WD silt = water dispersible silt, DR = Dispersion ratio, CDR = clay dispersion ratio. }
\end{tabular}

Table 5: Percent water-stable aggregates, mean-weight diameter (MWD) and aggregate stability of

the soils of Opi-Nsukka

\begin{tabular}{|c|c|c|c|c|c|c|c|}
\hline $\begin{array}{l}\text { Rumen digesta }\left(\mathrm{gkg}^{-1}\right. \\
\text { soil) }\end{array}$ & $>2$ & $2-1$ & $1-0.5$ & $0.5-0.25$ & $<0.25$ & MWD & AS \% \\
\hline 0 & 0.28 & 6.15 & 25.19 & 33.61 & 34.77 & 0.49 & 54.7 \\
\hline 50 & 7.98 & 15.29 & 28.25 & 25.59 & 22.89 & 0.84 & 69.3 \\
\hline 100 & 26.55 & 18.65 & 18.53 & 16.77 & 19.49 & 1.40 & 72.7 \\
\hline 150 & 34.26 & 13.99 & 14.49 & 12.79 & 20.24 & 1.75 & 75.3 \\
\hline $\operatorname{LSD}_{0.05}$ & 8.60 & 4.875 & 3.919 & 3.764 & 6.99 & 0.2816 & 6.54 \\
\hline
\end{tabular}

$\mathrm{MWD}=$ mean weight diameter, $\mathrm{AS}=$ aggregate stability .

\section{Chemical Properties}

The soil $\mathrm{pH}$ in water, exchangeable bases $(\mathrm{Ca}$, $\mathrm{Mg}, \mathrm{K}$, and $\mathrm{Na}$ ), exchangeable acidity $(\mathrm{Al}$ and $\mathrm{H})$, ECEC, total nitrogen, and organic matter at different rates of rumen digesta application are presented in Fig 1. As the rate of rumen digesta application increased the soil $\mathrm{pH}$, exchangeable sodium $(\mathrm{Na})$, exchangeable potassium $(\mathrm{K})$, effective cation exchange capacity (ECEC), and organic matter content increased while the exchangeable acidity decreased.

From Figure 1 it was recorded that untreated soil had high soil acidity $(\mathrm{pH}=3.8)$ while application at $50 \mathrm{~g}$ rumen digesta produced less acidic condition. At 150 LRD, soil $\mathrm{pH}$ appreciated by $15.4 \%$ relative to LRD at $50 \mathrm{~g}$, due to significant $(\mathrm{p}=0.05)$ increase in exchangeable cation contents in the soil colloidal complex. Low $\mathrm{pH}$ of 3.8 obtained with the application of rumen digesta at 0 and 6.6 with $50 \mathrm{gkg}^{-1}$ soil might be associated to loss of exchangeable bases resulting from displacement reactions in the soil colloidal complex. Soil acidity has been blamed on excessive rainfall that necessitated eluviations and leaching losses of cations under field conditions. The rise in $\mathrm{pH}$ of the treated soils above 6 may have effect on the nutrient availability in the soil, because this is the $\mathrm{pH}$ range for maximum nutrient availability in the soils (Brady and Weil, 2005). The improvement of soil $\mathrm{pH}$ in the treated soils confirms the liming effect of rumen digesta. Similar reports on the

liming effect of organic materials were shown by Duruigbo et al. (2006), Anon and Ubochi (2007), Okonkwo et al. (2009), Osemwota 2010 and Ekpe 2013.

Organic matter content of the untreated soil was $0.97 \%$ and ranged from $2.38 \%$ to $4.29 \%$ for treated soils. The organic matter content was highest in soils with treatment level of $150 \mathrm{~g} / \mathrm{kg}$ soil of rumen digesta. There were significant differences $(p=0.05)$ between the organic matter contents of untreated and treated soils. The increase in organic matter of the treated soils can be attributed to the increase in organic carbon and mineralization of the rumen digesta. This finding is in agreement with that of NRCS (1996) and Ekpe (2013) was noted that applying animal manure increases the supply of organic matter in the soil.

The total nitrogen content of the untreated soil was $0.010 \%$ but range from 0.014 to 0.020 for treated soils. The highest nitrogen content of treated soils of $0.020 \%$ was obtained from the application of $150 \mathrm{~g} / \mathrm{kg}$ soil of rumen digesta. This was significantly different $(\mathrm{p}=0.05)$ from the total nitrogen obtained from the control. Total nitrogen obtained from $150 \mathrm{gkg}$ - soil LRD was higher than that of $100 \mathrm{gkg}^{-}$soil, $50 \mathrm{gkg}^{-}$soil and $0 \mathrm{gkg}$ soil LRD by $10 \%, 30 \%$ and $50 \%$ respectively. This resulted from the incorporation of rumen digesta to the soil and 
agrees with the findings of Awodun (2008) and Okonkwo et al. (2009) that mineralization of organic wastes results in the release of organic bound nutrients in the soil notably N, P and K. However, there were no significant differences between the total nitrogen obtained from the applications of $50,100 \mathrm{~g} / \mathrm{kg}$ soil rumen digesta and the control. Rumen digesta appeared to have influenced the total nitrogen content of the treated soils. However substantial amount of the nitrogen may have been lost through volatilization losses from the waste (Prasad and De Datta 1979).

All exchangeable cations $\left(\mathrm{Ca}^{2+}, \mathrm{Mg}^{2+}, \mathrm{K}^{+}\right.$ and $\mathrm{Na}^{+}$) had significant $(\mathrm{p}=0.05)$ increases in the soil with increase in treatment application (Fig 1), a suggestion that the organic amendment had effect on the measured soil parameters. Exchangeable $\mathrm{K}^{+}$increased by $93.0 \%$ in LRD 150 relative to $L R D 0 \mathrm{~g}$. The values from LRD $50 \mathrm{~g}$ to $150 \mathrm{~g}$ were higher than the critical values of 0.16 to $0.20 \mathrm{cmolkg}^{-}$for crop production in the subtropical area (Isirima et al., as cited in Ezeaku, 2011). Findings are in agreement with what was reported by Osemwota (2010). The concentrations of the exchangeable cations in the treated soils improved; this shows that rumen digesta improved the exchangeable bases content in the soil. The increase in values may be as a result of increased soil $\mathrm{pH}$ which invariably has a liming effect on the soil and agrees with NRCS (1998) that increase in soil $\mathrm{pH}$ increases the availability of exchangeable bases. Increases in exchangeable bases due to application of organic residues have also been reported by Mbagwu (1992).

The untreated soil contained 1.5 $\mathrm{cmol} / \mathrm{kg}$ of $\mathrm{Al}^{3+}$ but after amendment the $\mathrm{Al}$ content was significantly reduced to $0.0 \mathrm{cmol} / \mathrm{kg}$. The $\mathrm{H}^{+}$content of the untreated soil was significantly different from the $\mathrm{H}^{+}$content of the treated soils. Rumen digesta significantly reduced the $\mathrm{H}^{+}$content of the soils. The $\mathrm{H}^{+}$ content of the untreated soils was $3.7 \mathrm{cmol} / \mathrm{kg}$, while that of the untreated soils were between 2.2 and $2.3 \mathrm{cmol} / \mathrm{kg}$. This also may have accounted for the increase in soil $\mathrm{pH}$ and reduction in acidity level. This result is in accordance with other works where organic manure reduced the $\mathrm{Al}^{3+}$ and $\mathrm{H}^{+}$content of the soil (Agboola and Odeyemi 1975; Charreau, 1975; Nwite; et al, 2012; Enueke; et al, 2013).

Effective cation exchange capacity contents in the treated soils were significantly different $(p=0.05)$ from that of the untreated soils. The content of ECEC in the controls was $7.2 \mathrm{cmol} / \mathrm{kg}$ while in the treated soils it varied from 11.1 to $14.9 \mathrm{cmol} / \mathrm{kg}$ (Fig. 1). Therefore it could be said that rumen digesta significantly increased the ECEC of the soils. This result is similar to other reports that showed that organic matter increases the ECEC of the soil. Examples of such works were those conducted by Egawa (1975), Nwite (2012) and Asadu and Nweke (1999). This also is in agreement with NRCS (1996) that organic matter retains nutrients by providing cation and anion exchange capacities. For the soils of the tropics, values of ECEC between 6 and $8 \mathrm{cmolkg}^{-1-}$ is regarded as low, 8 to $11 \mathrm{cmol} \mathrm{kg}^{-}$as medium and $>12 \mathrm{cmolkg}^{-1}$ as high (Enwezor et al. in Ezeaku, 2011). Based on these limits the amount of ECEC obtained in LRD 0 (control) and LRD $50 \mathrm{~g}$ was low and medium, respectively. The values obtained at LRD 100 and $150 \mathrm{~g}$ were high (Figure 1), indicating no response to $\mathrm{N}, \mathrm{P}$ and $\mathrm{K}$ fertilization for crops in the tropical area (Ezeaku, 2011).

\section{CONCLUSION}

Results of the study revealed that rumen digesta significantly increased the mean-weight diameter (MWD), aggregate stability (AS), soil $\mathrm{pH}$, total nitrogen (TN), exchangeable sodium $(\mathrm{Na})$, exchangeable potassium (K), effective cation exchange capacity (ECEC) and organic matter content of the studied soil. Application of rumen digesta had no significant effect on the texture, exchangeable calcium ( $\mathrm{Ca}$ ) and exchangeable magnesium $(\mathrm{Mg})$ contents of the soil. It significantly reduced the exchangeable aluminum $(\mathrm{Al})$ and hydrogen $(\mathrm{H})$ content of the soils.

For better sustainability of agricultural soils, 100 $\mathrm{g}$ of rumen digesta/kg soil is recommended to improve the physi-chemical properties of the soil of Opi since it gave the best results. Rates more than this would increase the soil $\mathrm{pH}$ to an alcidine level which would have a negative effect on crop productivity. This study recommends the use of rumen digesta as a form of liming material but with caution to avoid making the soil alkaline.

\section{REFERENCES}

Agbim, N.N. (1981). Potentials of cassava peels as a soil amendment. Corn growth, J. environmental qual 14.3:411-415.

Agboola, A.A. and Odeyemi, O. (1972). The effect of land use on the soil organic matter, exchangeable K, Available 
phosphorus and soil $\mathrm{pH}$ in the rainforest zone of western Nigeria. Nigeria Agricultural Journal. 2: 161168.

Anon, A.O. and Ubochi, C.I. (2007). Neutralization of soil acidity by animal manures. Mechanism of reactions, African Journal of Biotechnology 6(4): 364-368.

Asadu, C.L.A. and Nweke, F.I. (1999). Soils of arable crop fields in sub- Saharan Africa: Focus on cassava growing areas. Collaborative study of cassava in Africa. Working paper No. 18, IITA, Ibadan Nigeria.

Awodun, M.A. (2008). Effects of nitrogen released from rumen digesta and cow dung on soil and leaf nutrient content of Gboma (Solanum. Macrcapon .L) Journal of Applied Biosciences. 7: 202-206.

Bouyoucos, G. J. (1962). Hydrometer method for making particle size analysis of soils. Soil Science Society of America Proceedings. 26: 464-465.

Brady, N. C. and Weil, R. R. (2005). The nature and properties of soils, 13th ed. Delhi: Pearson Education.

Bremner, J. M. and Mulvaney, C. S. (1982). Nitrogen. In A. I. Page, R. H. Miller, \& D. R. Keeney (Eds.), Method of soil analysis, part 2, Agron. Monogr. $9,2^{\text {nd }}$ ed. Madison: ASA. pp. 159 165)

Chaney, K. and Swift, R.S. (2006). The influence of organic matter on aggregate stability in some british soils. European Journal of Soil Science. Vol. 35 (2):223-230

Duruigbo, C.J., Obiefuna, J.C., Onweremmadu, E.U., Ogbede, K.O., Ihejirika, G.F. and Obilo, O.P. (2006). Effects of poultry manure rates on soil acidity in an ultisol. In: Proceedings of Agricultural Society of Nigeria Annual Conference, Umudike.

Ekpe, I.I. (2013). Effect of Fresh Rumen Digesta on Soil Chemical Properties and Yield of Cucumber (Cucumis sativus) In Abakaliki Southeast Nigeria. International Journal of Food, Agriculture and Veterinary Sciences. Vol. 3 (2): 110-117

El hadj, B., Saad, A.H. and Aziz, L. (2013). Short-term effect of organic residue incorporation on soil aggregate stability along gradient in salinity in the lower Cheliff plain (Algeria). African Journal of Agricultural research. Vol. 8 (19): 2144-2152

Enueke, E.C., Ojeifo I.M. and Nnaji, G.U. (2013). Residual effects of organic manure and inorganic fertilizer on maize grain weight and soil properties in Asaba area of Delta state. International Journal of Advanced Biological Research. Vol. 3(3): 433-442.

Ezeaku, P.I. (2011). Soil quality as influenced by landuse and management in the southern guinea savanna of Nigeria. Nig. J. of Soil and Env. Res. 9:1-11

Kemper, W.D. and Rosenau, R.C. (1986). Aggregate stability and size distribution. In: Method of Soil Analysis. Part 1. Physical and Mineralogical Methods, Soil Science Society of American Agronomy Monograph No. 9, 2nd ed., pp. 425440.

Lombin, C.G., Adepetu, J.A. and Ayotade, K.A. (1991). Complementary use of organic manure and inorganic fertilizers in arable crop production. Proceedings of a national organic fertilizer seminar, Kaduna Nigeria. pp 146-162

Maclean, E.O. (1982). Soil pH and Line requirements. In: edited by Page et al.,, Methods of soil Analasysis part II, American Society of Agronomy 9 Madison WIUSA. Pp 199-234.

Mbagwu, J.S.C. (1985), Subsoil productivity of an ultisol in Nigeria as influenced by organic waste and inorganic fertilizers amendments. Soil science 140: 436-441.

Mbagwu, J.S.C. (1992). Improving the productivity of a degraded ultisols in Nigeria using organic and inorganic amendments, Part 2: chemical properties and maize yield Biores. Technol 42: 149-154.

Mbah, C.N. and Onweremadu, E.U. (2009). Effect of organic and mineral fertilizer inputs on soil and maize grain yield in an acid ultisol in Abakaliki-south eastern Nigeria. American-eurasian Journal of agronomy 2(1): 07-12. 
Nelson, D. W. and Sommers, L. S. (1982). Total carbon In A. I. Page, R. H. Miller, \& D. R. Keeney (Eds.), Method of soil analysis, part 2, Agron Monogr 9, $2^{\text {nd }}$ ed. Madison: ASA. pp. 539-579.

NRCS (1996). Soil Quality Indicators: Organic matter, soil quality information sheet.

NRCS (1998). Soil quality indicators: $\mathrm{pH}$, soil Quality information sheet.

Nwanta, J.A., Onunkwo, J. and Ezenduka, E. (2010). Analysis of Nsukka metropolitan abattoir solid waste and its bacterial contents in South Estearn Nigeria: Public Health implications. Archives of Environmental \& Occupational Health, 65(1): 21-26.

Nwite, J.C., Essien, B.A., Amaele, M.U., Obalum, S.E., Keke, C.I. and Igwe, C.A. (2012). Supplementary use of poultry droopings and rice-husk waste as organic amendments in southeastern Nigeria. 1: soil chemical properties and maize yield. Libyan Agriculture Research Center Journal International. 3(2): 90-97.

Nwite, J.N. (2013). Effect of different rates of poultry manure on soil properties and grain yield of maize at Abakaliki Ebonyi state, Nigeria. Crop Science Society of Nigeria book of abstracts. Pp140

Odu, C.T.I. and Mba, C.C. (1991). Microbiological consideration for maximizing nutrient availability through organic fertilization. Proceedings of a national organic fertilizer seminar, Kaduna Nigeria. pp 67-80.
Okonkwo, B.C.N., Okoro, I.K., Chukwu, G.O., Okonkwo, J.C. and Olojede, O.A. (2009). Agronomic potentials of defatted Palm kernel Cake in sweet potato production on typic paleudult. Proceedings of the 43rd Annual Conference of Agricultural Society of Nigeria, Abuja. Pp 56-59.

Omaliko, C.P.E. (1985). Dung decomposition and its effect on the soil component of a grass land ecosystem. Tropical Ecology. 25: 214-220

Omaliko, C.P.E. and Agbim, N.N. (1983). Forage corn response to rice mill waste and fertilizer. J. Environmental Qual 12: 320-324.

Prasad, R. and De Datta, S. U. (1979). Increasing fertilizer nitrogen efficiency in wet land rice. Rice Research Institute. Report, Manila, Philippines. pp. 465484

Sridar, M.K.C. (2006). Solid waste management in the $21^{\text {st }}$ century in Nigeria. In proceeding of the fourth annual conference of senate on the Nigerian environment organized at port harcourt by senate committee on environment and ecology, National assembly, July 5-7 Abuja. pp 1-11

Steel, R.D. and Torrie, J.H. (1980). Principles and procedures of ststistics. A Biometric Approach. $2^{\text {nd }}$ edition. McGraw Hill Book Coy, In, N.Y. U.S.A., 663ppt xxi. 